\title{
Application of Bilingual Classroom Learning to English Language Skills at SD Muhammadiyah 1 Gempol Elementary School Students [Penerapan Pembelajaran Kelas Bilingual Terhadap Kemampuan Berbahasa Inggris Siswa SD Muhammadiyah 1 Gempol]
}

\author{
Friza Brillianty Shabrina*, Muhlasin Amrullah \\ \{ frizabs@gmail.com, muhlasin1@umsida.ac.id\} \\ Fakultas Psikologi dan Ilmu Pendidikan,Universitas Muhammadiyah Sidoarjo, Indonesia
}

\begin{abstract}
This study aims to determine the history of the bilingual class and the application of bilingual class learning at SD Muhammadiyah 1 Gempol. The research process uses data collection methods with interviews and observations. The subject of this research is the Principal of SD Muhammadiyah 1 Gempol. The focus in this research is how the history or the beginning of the bilingual class and how the implementation of bilingual class learning. Based on the results of the research, the bilingual class at SD Muhammadiyah 1 Gempol is a class that uses 2 languages in its delivery, namely Indonesian and English which were initiated by the principal at the SD and as a different brand than other schools in the Gempol area. The application of bilingual classroom learning uses 3 additional lessons using books with Cambridge Curriculum Singapore. Read, write, and count selections are made for students who will enter the bilingual class. There is a change in the requirements for bilingual classes that are carried out so that their implementation can be carried out properly.
\end{abstract}

Keywords: Application of Learning, Bilingual Class, English.

\begin{abstract}
Abstrak. Penelitian ini bertujuan untuk mengetahui sejarah kelas bilingual dan penerapan pembelajaran kelas bilingual di SD Muhammadiyah 1 Gempol. Proses penelitian menggunakan metode pengambilan data dengan wawancara dan observasi. Subjek penelitian ini adalah Kepala Sekolah SD Muhammadiyah 1 Gempol. Fokus dalam penelitian ini adalah bagaimana sejarah atau awal mula diadakannya kelas bilingual dan bagaimana penerapan pembelajaran kelas bilingual. Berdasarkan hasil penelitian kelas bilingual di SD Muhammadiyah 1 Gempol merupakan kelas yang dalam penyampaiannya menggunakan 2 bahasa yaitu bahasa Indonesia dan bahasa inggris yang dicetuskan sendiri oleh kepala sekolah di SD tersebut dan sebagai different brand daripada sekolah-sekolah lain di wilayah Gempol. Penerapan pembelajaran kelas bilingual menggunakan 3 pelajaran tambahan yang menggunakan buku dengan Cambridge Curriculum Singapore. Dilakukan seleksi baca, tulis, dan hitung terlebih dahulu bagi siswa yang akan masuk kelas bilingual. Adanya perubahan syarat kelas bilingual yang dilakukan agar penerapannya dapat terlaksana dengan baik.
\end{abstract}

Kata Kunci: Penerapan Pembelajaran, Kelas Billingual, Bahasa Inggris 


\section{Pendahuluan}

Pendidikan merupakan salah satu hak setiap warga negara dan berhak menerimanya. Hak warganya dalam mendapatkan pendidikan seperti halnya dalam memenuhi amanat dalam pembukaan UUD 1945 yakni mencerdaskan kehidupan bangsa. Tentu pendidikan memiliki peran yang sangat besar dalam kemajuan dan mencerdaskan bangsa terutama pembentukan karakter bagi anak serta kompetensi anak. dalam membentuk kompetensi anak yang unggul maka pentingnya peran sekolah dalam pemberikan pengajaran yang medukung dengan perkembangan zaman. Peran sekolah sangat penting untuk mendukung siswa memiliki kompetensi yang unggul dengan memberikan seluruh fasilitas pendidikan serta strategi pembelajaran yang mumpuni. Salah satu strategi khusus dalam meningkatkan kompetensi siswa adalah kompetensi dalam berbahasa. [1]

Bahasa merupakan alat komunikasi antar manusia di dunia maka penguasaan bahasa selain bahasa ibu, yaitu bahasa internasional seperti bahasa inggris menjadi tuntutan yang mendesak. kepentingan bahasa itu hampir mencakupi segala bidang kehidupan karena segala sesuatu yang dihayati, dialami, dirasakan, dan dipikirkan oleh seseorang hanya dapat diketahui oleh orang lain ketika telah diungkapkan dengan kata-kata melalui bahasa, baik dalam bentuk tulisan maupun lisan. Bahasa inggris merupakan bahasa asing pertama yang diajarkan di Indonesia sebagai kebijakan pemerintah dalam surat keputusan Menteri Pendidikan dan Kebudayaan Nomor 060/U/1993 tanggal 25 Februari 1993 tentang dimungkinkannya program bahasa Inggris lebih dini debagai salah satu mata pelajaran muatan lokal. Kebijakan ini telah mendapat sambutan positif dari masyarakat, terutama oleh sekolahsekolah dasar yang merasa memerlukan dan mampu menyelenggarakan pembelajaran bahasa inggris. Untuk itulah penelitian ini dilakukan untuk mengetahui penerapan pembelajaran kelas bilingual dalam meningkatakan kemampuan bahasa inggris siswa SD Muhammadiyah 1 Gempol. [2]

\section{Metode Penelitian}

Penelitian ini menggunakan metode penelitian kualitatif deskriptif. Pendekatan kualitatif merupakan proses penelitian untuk memahami masalah-masalah sosial atau manusia dengan menganalisis kata-kata untuk menciptakan gambaran kompleks dan menyeluruh, serta melaporkan pandangan informasi terperinci yang diperoleh dari para sumber informasi dalam lingkungan alami. Pendekatan kualitatif juga bertujuan untuk menyelidiki,menemukan, menggambarkan, serta menjelaskan kualitas atau keistimewaan dari pengaruh sosial yang tidak dapat dijelaskan, diukur, atau digambarkan melalui pendekatan kuantitatif. Teknik pengambilan data dalam penelitian ini melalui wawancara, dokumentasi dan observasi, adapun trianggulasi yang di pakai dalam penelitian ini adalah trianggulasi teknik. Penggunaan metode kualitatif ini dimaksudkan untuk memperoleh gambaran mengenai penerapan pembelajaran kelas bilingual di SD Muhammadiyah 1 Gempol.

\section{Hasil dan Pembahasan}

Bahasa diyakini mempunyai kedudukan dan kekuatan yang sangat penting. Sebagai sarana komunikasi, teks menjadi kekuatan pendukung, dan penyebar paling efektif. Oleh karena itu, di era globalisasi ini setiap individu dituntut memiliki kemampuan yang kuat dalam penguasaan ilmu-ilmu yang mendasari teknologi yaitu Matematika, Ilmu Pengetahuan Alam, dan bahasa internasional atau global yaitu bahasa inggris. Keunggulan sumber daya manusia akan 
menentukan kemenangan bersaing antar bangsa. Kelas bilingual merupakan salah satu cara untuk sumber daya manusia dapat memiliki keunggulan dalam berbahasa.[3]

SD Muhammadiyah $1 \mathrm{Gempol}$ terdapat dua kelas yaitu kelas reguler dan kelas billingual. Kelas reguler adalah kelas umum yang mengikuti sistem pembelajaran pada umumnya. Misalnya siswa SD bersekolah selama 6 tahun sesuai dengan kurikulum K-13. Sedangkan kelas billingual adalah kelas dwibahasa sebagai pengantar pembelajaran kepada siswa. Billingual sendiri adalah sebuah metode ataupun sistem penyampaian materi pembelajaran dengan menggunakan 2 bahasa, dengan tujuan untuk menguatkan kompetensi siswa dalam berbahasa Inggris. Billingual ini tidak hanya diterapkan ketika penyampaian materi akan tetapi juga di terapkan dalam komunikasi sehari-hari antara murid dan guru. Banyak negara maju menggunakan sistem tersebut yang bertujuan untuk mempercepat perbaikan mutu terhadap pemahaman anak, khususnya mutu pendidikan tidak hanya berskala nasional akan tetapi lebih diakui dalam internasional. Pada prinsipnya sistem bilingual menggunakan kurikulum tingkat satuan pendidikan yang diperkaya dengan kurikulum internasional. Materi ajarnya berkaitan dengan pengembangan life skills .

Proses awal terbentuknya kelas billingual di SD Muhammadiyah 1 Gempol merupakan hasil dari motivasi kepala sekolah SD Muhammadiyah 1 Gempol sendiri yaitu Bapak. Miftakhuddin, M.Pd, i. Beliau melakukan sebuah different brand sendiri daripada lembaga lainlain di wilayah Gempol. Motivasi tersebut muncul ketika beliau berbincang-bincang dengan teman-temannya dari sekolah dasar Muhammadiyah yang berada di luar daerah Pasuruan seperti Sidoarjo, Gresik, dan Surabaya. Beliau mengatakan teman-temannya sudah banyak yang mendirikan kelas ICP yaitu International Class Program. Dari situlah kemudian beliau berusaha agar bisa memiliki kelas yang berbeda seperti itu dari sekolah-sekolah lainnya di SD Muhammadiyah 1 Gempol tempat ia mengajar. Kelas billingual di SD Muhammadiyah 1 Gempol sudah berjalan 3 tahun yang mana siswa-siswa tersebut sudah berada di kelas 3 SD. [4]

Dalam penerapan pembelajaran kelas bilingual di SD Muhammadiyah 1 Gempol, siswa menerima 3 pelajaran tambahan yaitu matematika (math champion), IPA (science) dan hangout yang disampaikan dalam bahasa inggris oleh guru bahasa inggris dan guru IPA yang mana sebelumnya guru-guru tersebut sudah mendapat pelatihan dari kerjasama pihak penyedia buku berdasarkan 3 pelajaran tambahan. Dalam materi hangout ini fokus dalam bahasa inggris seperti edu games atau fun learning untuk peserta didik yang bisa dilaksanakan online. Materi yang diajarkan di kelas bilingual dipilih sesuai dengan tingkat perkembangan kognitif siswa dan mudah ditemukan dalam kehidupan sehari-hari sehingga tidak menyulitkan siswa dalam mempelajarinya. Penerapan menggunakan referensi buku tersebut diharapkan kemampuan bahasa inggris siswa SD Muhammadiyah 1 Gempol yang mencakup 4 poin penting bahasa yaitu speaking, reading, writing, dan listening dapat tercapai. 3 buku yang dipilih menggunakan acuan buku dari mentari book yang sudah diselaraskan dengan Kurikulum Nasional Indonesia tahun 2013 dan Cambridge Curriculum Singapore. Maka secara tidak langsung SD Muhammadiyah 1 Gempol menggunakan 3 kurikulum yaitu Kurikulum Nasional Indonesia tahun 2013, Cambridge Curriculum Singapore, dan kurikulum ISMUBA.

Dari hasil wawancara, kepala sekolah menuturkan bahwa jumlah siswa per kelas di SD Muhammadiyah 1 Gempol sekitar 24 siswa. Dari 24 siswa tersebut, 14 siswa berada di kelas reguler dan 10 siswa lainnya berada di kelas bilingual. Meskipun dikatakan kelas bilingual ini belum bisa memiliki banyak siswa per kelas nya tetapi pihak sekolah tetap optimis dalam mejalankan kelas tersebut. Dalam pelaksanaan program kelas bilingual, diadakan proses seleksi bagi peserta didik yaitu mereka di seleksi baca, tulis, dan hitung. Namun setelah dalam 1 tahun pembelajaran dan di evaluasi, sekolah merasa hal itu kurang maksimal dan tidak berhasil karena terdapat beberapa peserta didik yang bisa baca, tulis, dan hitung, secara finansialnya lemah. 
Dalam kelas bilingual harga buku dan adanya assessment english learning yang memerlukan biaya cukup mahal. Untuk mempunyai sumber referensi atau buku bacaan, mereka tidak mampu untuk membeli. Sehingga pada tahun kedua, sekolah merubahnya dengan cara membuat syarat untuk orang tua peserta didik yang memiliki finansial yang dikatakan mampu dan lolos seleksi dapat masuk di kelas bilingual. Hal itu dilakukan agar penerapan pembelajaran kelas bilingual dapat berjalan dengan baik.

Kendala yang dialami dalam penerapan kelas bilingual ini adalah karena pemikiranpemikirkan lama oleh para wali murid mengenai perbedaan kelas reguler dan bilingual seperti pihak sekolah akan lebih cenderung memihak siswa-siwi di kelas bilingual daripada kelas reguler. Ini adalah sebuah tantangan tersendiri untuk pihak sekolah terutama Kepala Sekolah SD Muhammadiyah 1 Gempol bagaimana cara untuk menepis pemikiran tersebut. Disamping itu, para wali murid memiliki respon baik dengan adanya kelas bilingual. Siswa-siswi pun senang dan antusias berada di kelas tersebut bahkan beberapa siswa ingin pindah ke kelas bilingual.

\section{Kesimpulan}

Kelas bilingual adalah kelas dwibahasa sebagai pengantar pembelajaran kepada siswa. Kepala sekolah SD Muhammadiyah 1 Gempol melakukan sebuah different brand kelas bilingual daripada lembaga lain-lain di wilayah Gempol. Guru-guru mendapatkan pelatihan dari kerjasama pihak penyedia buku berdasarkan 3 pelajaran tambahan yaitu matematika (math champion), IPA (science) dan hangout yang disampaikan dalam bahasa inggris. Adanya perubahan syarat pada tahun kedua dengan merubah syarat untuk orang tua peserta didik yang memiliki finansial yang dikatakan mampu dan lolos seleksi lah yang dapat masuk di kelas bilingual. Terdapat kendala adanya beberapa pemikiran-pemikirkan lama oleh para wali murid mengenai perbedaan kelas reguler dan bilingual yang menjadikan tantangan tersendiri untuk pihak sekolah terutama Kepala Sekolah SD Muhammadiyah 1 Gempol bagaimana cara untuk menepis pemikiran tersebut. Namun kelas bilingual di SD muhammadiyah 1 Gempol tetap berjalan dengan baik dan eksis di wilayah gempol di samping adanya beberapa kendala yang ada.

\section{Ucapan Terima Kasih}

Dengan terselesaikannya artikel ini penulis mengucapkan terima kasih yang sedalam-dalamnya kepada Allah S.W.T atas limpahan karunia dan hidayahnya sehingga penulis dapat melaksanakan observasi dan menyelesaikan artikel. Bapak Dosen Muhlasin Amrullah,M.Pd.I selaku Dosen kami atas bimbingan, arahan dan koreksinya selama penyusunan dan penulisan artikel. Bapak Miftakhuddin, M.Pd, i. Selaku kepala sekolah di SD Muhammadiyah 1 Gempol yang telah memberikan izin dan memberikan informasi terkait pembelajaran di sekolah untuk observasi.

\section{References}

[1] Badiatun, Muniroh. 12505184006 (2021). Strategi Pembelajaran Sistem Bilingual Dalam Meningkatkan Kompetensi Bahasa Inggris Siswa (Studi Multikasus di SD Internasional Zumrotus Salamah Tawangsari Kedungwaru Tulungagung dan MI AlAzhar Bandung Tulungagung). Available: http://repo.iain-tulungagung.ac.id/17986/ 
[2] Sugianto, B. (2014). Optimalisasi Penerapan Kelas Bilingual menuju Pembelajaran Efektif di SMP Negeri 1 Dukun Gresik. Jurnal Kebijakan Dan Pengembangan Pendidikan,2(1).Available

https://ejournal.umm.ac.id/index.php/jkpp/article/view/1732

[3] Zahrotul A. (2013). Implementasi Program Bilingual Untuk Meningkatkan Keterampilan Bahasa Inggris Siswa di Madrasah Ibtidaiyah Khadijah Malang. Skripsi. Tidak Diterbitkan. Fakultas Tarbiyah. Universitas Islam Negeri Maulana Malik Ibrahim: Malang Available : https://docplayer.info/56918521-Implementasi-programbilingual-untuk-meningkatkan-keterampilan-bahasa-inggris-siswa-di-madrasahibtidaiyah-khadijah-malang.html

[4] Ulin N. (2014). Meningkatkan Kualitas Pelayanan Perpustakaan Dengan Pendekatan Bilingual. 2(1).

72. Available https://journal.iainkudus.ac.id/index.php/Libraria/article/view/1190/1083 